JURNAL PENDIDIKAN, p-ISSN 2715-095X, e-ISSN 2686-5041

Volume 29, No.3, Nopember 2020 (241-252)

Online: http://journal.univetbantara.ac.id/index.php/jp

\title{
Peningkatan Keaktifan dan Hasil Belajar IPA Melalui Metode Eksperimen pada Peserta Didik Kelas VII H SMP MTA Gemolong Kabupaten Sragen Semester I Tahun Pelajaran 2019/2020
}

\author{
Sumargo \\ Guru SMP MTA Gemolong, E-mail: masmargo7182@gmail.com
}

\begin{abstract}
Abstrak : Penelitian ini dilakukan kepada peserta didik kelas VII H SMP MTA Gemolong Kabupaten Sragen Semester I Tahun Pelajaran 2019/2020. Adapun metode pembelajaran yang digunakan dalam penelitian ini adalah metode eksperimen. Metode eksperimen memiliki kelebihan memberi kesempatan kepada peserta didik untuk memahami konsep dengan cara melakukan percobaan/ eksperimen sehingga membuat peserta didik aktif dalam pembelajaran. Peserta didik mengalami secara langsung dalam menemukan konsep sehingga dalam pembelajaran ini seakan memberi keleluasaan kepada peserta didik untuk mencari pemahamannya sendiri dengan cara mengumpulkan data, menganalisis data, membangun hipotesis, dan percobaan untuk menarik kesimpulan. Hasil Penelitian Tindakan Kelas ini yaitu hasil rerata skor keaktifan peserta didik kondisi awal 53.13\%, pada siklus I meningkat menjadi $70.00 \%$, pada siklus II meningkat menjadi menjadi $76.25 \%$, sehingga terjadi peningkatan sebesar $6.25 \%$. Sedangkan rerata hasil belajar pada kondisi awal 67.19, pada Siklus I mengalami peningkatan menjadi 72.25 , dan pada Siklus II Rerata menjadi 76,41 , sehingga terjadi peningkatan rerata sebesar 4.16. Hasil penelitian menyatakan bahwa penerapan metode eksperimen dapat meningkatkan keaktifan dan hasil belajar IPA pada peserta didik kelas VII H SMP MTA Gemolong Kabupaten Sragen Semester I Tahun Pelajaran 2019/2020.
\end{abstract}

Kata-kata Kunci: Metode Eksperimen, Keaktifan Belajar dan Hasil Belajar.

\section{Increasing Activeness and Science Learning Outcomes through Experimental Methods in Class VII H Students of SMP MTA Gemolong Sragen Regency, Semester I Academic Year 2019/2020}

Sumargo

The Teacher of SMP MTA Gemolong,E-mail: masmargo7182@gmail.com

\begin{abstract}
This research was conducted on class VII H students of SMP MTA Gemolong Sragen Regency in the first semester of the 2019/2020 academic year. The learning method used in this research is the experimental method. The experimental method has the advantage of giving students the opportunity to understand the concept by conducting experiments / experiments so that it makes students active in learning. Students experience firsthand in finding concepts so that in this learning it seems to give flexibility to students to seek their own understanding by collecting data, analyzing data, building hypotheses, and experimenting to draw conclusions. The results of this Classroom Action Research are the results of the mean score of the activeness of students in the initial conditions of $53.13 \%$, in the first cycle it increased to $70.00 \%$, in the second cycle it increased to $76.25 \%$, resulting in an increase of $6.25 \%$. While the mean of learning outcomes in the initial conditions was 67.19, in Cycle I it increased to 72.25, and in Cycle II it was 76.41, so there was an increase in the mean of 4.16. The results of the study stated that the application of the experimental method could increase the activeness
\end{abstract}


and learning outcomes of science learning in class VII H students of SMP MTA Gemolong, Sragen Regency, semester I of the 2019/2020 academic year.

Keywords: Experimental Methods, Learning Activeness and Learning Outcomes

\section{Pendahuluan}

Ilmu Pengetahuan Alam (IPA) kelas VII. IPA merupakan ilmu pengetahuan tentang gejala alam yang dituangkan berupa fakta, konsep, prinsip dan hukum yang teruji kebenarannya dan melalui suatu rangkaian kegiatan dalam metode ilmiah., oleh sebab itu maka konsep-konsep dasar IPA harus dikuasai peserta didik sejak dini, yang akhirnya hasil belajar peserta didik dapat mencapai kriteria ketuntasan minimal (KKM) serta terampil dan dapat menerapkan dalam kehidupan sehari-hari. Didalam mewujudkan tercapainya KKM perlu adanya strategi pembelajaran dalam menunjang terwujudnya seluruh kompetensi yang dimuat dalam kurikulum 2013, yang salah satu kompetensi intinya adalah memahami dan menerapkan pengetahuan (faktual, konseptual, dan prosedural) berdasarkan rasa ingin tahu tentang ilmu pengetahuan, teknologi, seni, budaya terkait fenomena dan kejadian di lingkungan sekitar siswa dalam kehidupan sehari-hari. Lingkungan sebagai salah satu sumber belajar yang nyata, dapat digunakan sebagai sarana untuk memperdalam materi dalam mata pelajaran IPA. Oleh karena itu, pembelajaran IPA dapat melibatkan siswa aktif, mengalami sendiri, menemukan dan mengembangkan keterampilan yang diperoleh, sedangkan guru berperan sebagai pembimbing dan fasilitator. Agar peserta didik bisa menguasai semua yang diajarkan oleh guru, peserta didik harus aktif dalam mengikuti proses pembelajaran. Keaktifan sebagai daya penggerak yang ada di dalam diri seseorang untuk melakukan aktivitas-aktivitas tertentu demi tercapainya suatu tujuan. Pentingnya peranan keaktifan dalam proses pembelajaran perlu dipahami oleh pendidik agar dapat melakukan berbagai bentuk tindakan atau bantuan kepada peserta didik. Usaha untuk meningkatkan keaktifan belajar peserta didik memerlukan kondisi tertentu yang mengedepankan keterlibatan dan keaktifan peserta didik dalam pembelajaran. Maka diharapkan guru dapat memilih model yang tepat dalam pembelajaran sehingga dapat meningkatkan keaktifan belajar peserta didik.

Namun yang terjadi di kelas selama ini, guru hanya cenderung mengaplikasikan konsep. Peserta didik mengalami kesulitan belajar IPA di kelas. Akibatnya peserta didik kurang menghayati atau memahami konsep-konsep IPA, akibatnya hasil belajar IPA rendah dan peserta didik mengalami kesulitan untuk mengaplikasikan IPA dalam kehidupan sehari-hari. Keaktifan peserta didik dalam belajar IPA sekarang ini dirasa sangat kurang. Peserta didik masih menganggap IPA adalah pelajaran yang sulit dan membosankanterutama untuk IPA Fisika yang banyak perhitungan dan rumus-rumus, sehingga untuk mengikuti jalannya proses pembelajaran peserta didik merasa malas. Ini masih banyak peserta didik yang malas dankurang memperhatikan materi yang disampaikan guru, ada sebagian peserta didik justru asyik ngobrol sendiridengan temannya, menyanyi sendiri yang dapat mengganggu konsentrasi temannya, mengantuk bahkan sampai ada yang merebahkan kepala tidur di atas meja, mereka merasa tidak butuh dengan IPA. Kondisi seperti ini yang menyebabkan nilai hasil belajar rendah. Dari hasil perolehan 
nilai pada kondisi awal sebelum melakukan tindakan, nilai rata-rata hanya mencapai 67.19 dari nilai KKM 70. Dan peserta didik yang tuntas hanya mencapai $43.75 \%$ dari jumlah seluruh siswa. Nilai rata-rata serta ketuntasan yang masih rendah dibawah KKM, perlu segera dicarikan jalan keluar dari permasalah yang ada di dalam kelas tersebut dan juga perlu segera dilakukan suatu tindakan untuk menyelesaikannya. Salah satu penyelesainnya yang harus segera dilakukan adalah dengan memperbaiki proses kegiatan belajar mengajar dengan metode pembelajaran yang menekankan pada keaktifan peserta didik sehingga potensi peserta didik dapat berkembang secara maksimal. Pendekatan yang dapat digunakan pembelajaran IPA khususnya materi Suhu dan perubahannya adalah melalui metode eksperimen, karena metode ini dapat mendorong kemauan dan membangkitkan keaktifan belajar peserta didik. Atas dasar pemikiran tersebut, maka peneliti mengambil judul Upaya Meningkatan Keaktifan dan Hasil Belajar IPA Materi Suhu dan Perubahannya Melalui Metode Eksperimen Pada Peserta Didik Kelas VII H SMP MTA Gemolong Kabupaten Sragen Semester I Tahun Pelajaran 2019/2020.

Dari uraian di atas dapat dirumuskan permasalahan dalam penelitian ini sebagai berikut: (1) Bagaimanakah penerapan metode eksperimen dapat meningkatkan keaktifan belajar IPA pada materi suhu dan perubahannya bagi peserta didik kelas VII H SMP MTA Gemolong Kabupaten Sragen semester I tahun pelajaran 2019/2020?, (2) Bagaimanakah penerapan metode eksperimen dapat meningkatkan hasil belajar IPAmateri suhu dan perubahannya bagi peserta didik kelas VII H SMP MTA Gemolong Kabupaten Sragen semester I tahun pelajaran 2019/2020?

Tujuan yang ingin dicapai dari penelitian ini adalah untuk: (1) Meningkatkan keaktifan belajar IPA pada materi suhu dan perubahannya melalui penerapan metode eksperimen bagi peserta didik kelas VII H SMP MTA Gemolong Kabupaten Sragen semester I tahun pelajaran 2019/2020, (2) Meningkatkan hasil belajar IPA pada materi suhu dan perubahannya melalui penerapan metode eksperimen bagi peserta didik kelas VII H SMP MTA Gemolong Kabupaten Sragen semester I tahun pelajaran 2019/2020. Aktif didefinisikan sebagai metode pengajaran yang melibatkan siswa secara aktif dalam proses pembelajaran. Pembelajaran pada hakekatnya untuk mengembangkan aktivitas dan kreativitas peserta didik melalui berbagai interaksi dan pengalaman belajar. Pembelajaran aktif mengkondisikan agar siswa selalumelakukan kegiatan belajar secara aktif dan berfikir tenang, fokus, dengan apa yang dilakukan selama pembelajaran (Warsono dan Hariyanto, 2013: 12). Keaktifan belajar siswa merupakan unsur dasar yang penting bagi keberhasilan proses pembelajaran. Keaktifan adalah kegiatan yang bersifat fisik maupun mental, yaitu berbuat dan berfikir sebagai suatu rangkaian yang tidak dapat dipisahkan (Sardiman, 2011: 98). Belajar yang berhasil harus melalui berbagai macam aktivitas, baik aktivitas fisik maupun psikis. Aktivitas fisik adalah siswa giat aktif dengan anggota badan, membuat sesuatu, bermain maupun bekerja, tidak hanya duduk dan mendengarkan, melihat atau hanya pasif. Siswa yang memiliki aktivitas psikis (kejiwaan) adalah jika daya jiwanya bekerja sebanyak-banyaknya atau banyak berfungsi dalam rangka pembelajaran. Keaktifan siswa dalam kegiatan belajar tidak lain adalah untuk mengkonstruksi pengetahuan mereka sendiri. Aktif dalam membangun pemahaman atas persoalan atau segala sesuatu yang mereka hadapi dalam proses pembelajaran. Menurut Sudjana (2005: 72) keaktifan siswa dapat dilihat dari keikutsertaan siswa dalam melaksanakan tugas belajarnya, terlibat dalam memecahkan masalah, bertannya kepada siswa lain atau guru apabila tidak memahami persoalan yang dihadapi, berusaha mencari berbagai informasi yang diperlukan untuk memecahkan masalah, melatih diri dalam memecahkan masalah atau soal, serta menilai 
kemampuan diri sendiri dan hasil-hasil yang diperoleh. Berdasarkan beberapa pengertian keaktifan diatas maka dapat disimpulkan bahwa keaktifan yaitu keikutsertaan siswa secara fisik atau mental untuk melakukn kegiatan secara aktif dalam proses pembelajaran yang sedang berlangsung dimana siswa berinteraksi dengan siswa lain maupun guru.

Berdasarkan pendapat para ahli di atas, indikator keaktifan belajar dalam penelitian ini adalah sebagai berikut: (1) Aktif dalam memperhatikan penjelasan guru, (2) Aktif dalam diskusi kelompok, (3) Aktif dalam kelompok, (4) Aktif dalam bekerjasama dalam kelompok, (5) Aktif mendengarkan pendapat teman lain. Pengertian hasil belajar menurut Menurut Syah dalam Giyono (2020: 131). "Hasil belajar adalah setiap macam perubahan yang khas sebagai hasil setelah belajar". Menurut Jihad dan Haris (2012:14) hasil belajar merupakan pencapaian bentuk perubahan perilaku yang cenderung menetap dari ranah kognitif, afektif, dan psikomotoris dari proses belajar yang dilakukan dalam waktu tertentu. Hasil belajar adalah kemampuan yang dimiliki siswa setelah ia menerima pengalaman belajarnya. Setelah suatu proses belajar berakhir, maka siswa memperoleh suatu hasil belajar. Hasil belajar mempunyai peranan penting dalam proses pembelajaran. Tujuan utama yang ingin dicapai dalam kegiatan pembelajaran adalah hasil belajar. Hasil belajar digunakan untuk mengetahui sebatas mana siswa dapat memahami serta mengerti materi tersebut. Menurut Hamalik (2004: 31) hasil belajar adalah pola-pola perbuatan, nilai-nilai, pengetahuan-pengetahuan, sikap-sikap, apresiasi, abilitas, dan keterampilan. Hasil belajar merupakan pengukuran dari penilaian kegiatan belajar atau proses belajar yang dinyatakan dalam symbol, huruf maupunkalimat yang menceritakan hasil yang sudah dicapai oleh setiap anak pada periode tertentu. Menurut Susanto (2013: 5) perubahan yang terjadi pada diri siswa, baik yang menyangkut aspek kognitif, afektif, dan psikomotor sebagai hasil dari belajar. Pengertian tentang hasil belajar dipertegas oleh Nawawi (dalam Susanto, 2013: 5) yang menyatakan bahwa hasil belajar dapat diartikan sebagai tingkat keberhasilan siswa dalam mempelajari materi pelajaran di sekolah yang dinyatakan dalam skor yang diperoleh dari hasil tes mengenal sejumlah materi pelajaran tertentu. Menurut Sudjana (2009: 3) "mendefinisikan hasil belajar siswa pada hakikatnya adalah perubahan tingkah laku sebagai hasil belajar dalam pengertian yang lebih luas mencakup bidang kognitif, afektif dan psikomotor". Berdasarkan pengertian hasil belajar di atas, dapat disimpulkan bahwa hasil belajar adalah suatu hasil yang diperoleh siswa yang berbentuk perubahan tingkah laku setelah siswa tersebut melakukan kegiatan belajar dan pembelajaran serta bukti keberhasilan yang telah dicapai oleh seseorang dengan melibatkan aspek kognitif, afektif maupun psikomotor, yang dinyatakan dalam symbol, huruf, angka maupun kalimat.

Pengertian metode eksperimen menurut Sumantri \& Permana (1999:157) adalah cara belajar mengajar yang melibataktifkan peserta didik dengan mengalami dan membuktikan sendiri proses dan hasil percobaan itu. Sedangkan menurut Hermawan, dkk, (2007:165), metode eksperimen adalah cara penyajian pelajaran di mana siswa melakukan percobaan dengan mengalami dan membuktikan sendiri sesuatu yang dipelajari. Dan menurut Dahar (2006:220), metode eksperimen adalah cara penyajian bahan pelajaran di mana siswa melakukan percobaan dengan mengalami untuk membuktikan sendiri sesuatu pertanyaan tau hipotesis yang dipelajari. Menurut Roestiyah dalam Mayangsari, dkk (2014:28) yang menyatakan bahwa metode eksperimen adalah salah satu cara mengajar, dimana siswa melakukan suatu percobaan tentang sesuatu hal, mengamati prosesnya serta menuliskan 
hasil percobaannya, kemudian hasil pengamatan itu disampaikan ke kelas dan dievaluasi oleh guru. Dengan demikian, dapat disimpulkan bahwa metode eksperimen adalah salah satu metode pembelajaran yang menitikberatkan pada aktivitas peserta didik melakukan percobaan dan membuktikan sendiri proses dan hasil percobaan sehingga guru hanya bertindak sebagai pembimbing.

Langkah-langkah penerapan metode eksperimen dalam pembelajaran adalah cara penyajian bahan pelajaran yang memungkinkan siswa melakukan percobaan untuk menemukan konsep-konsep terhadap apa yang dipelajari. Di bawah ini dikemukakan langkah-langkah pelaksanaan pembelajaran dengan menggunakan metode eksperimen yang diadaptasi dari Abimanyu (2008: 55) adalah sebagai berikut: (1) Kegiatan Persiapan meliputi: (a) Merumuskan tujuan pembelajaran yang ingin dicapai dengan metode eksperimen., (b) Menyiapkan materi pembelajaran yang diajarkan melalui eksperimen., (c) Menyiapkan alat dan bahan yang diperlukan dalam eksperimen, (d) Menyiapkan Lembar Kerja Siswa (LKS). (2) Kegiatan Pelaksanaan eksperimen meliputi; (a) Kegiatan Pembukaan: Melakukan apersepsi, Memotivasi siswa dengan bercerita, demonstrasi atau mengung- kapkan fakta yang ada kaitannya dengan materi pelajaran yang akan diajarkan., Mengemukakan tujuan pembelajaran yang ingin dicapai, dan prosedur eksperimen yang akan dilakukan. (b) Kegiatan Inti : Guru menciptakan kondisi yang memungkinkan timbulnya suatu permasalahan atau siswa diberi permasalahan yang harus dijawab melalui eksperimen, Membagikan LKS kepada masing-masing siswa, Siswa melaksanakan eksperimen berdasarkan panduan dan LKS yang telah disiapkan guru, Guru memantau pelaksanaan eksperimen dan membantu siswa yang mengalami kesulitan, Pelaporan hasil eksperimen dan diskusi balikan. (3) Kegiatan Penutup: Guru bersama siswa untuk merangkum / menyimpulkan hasil eksperimen, Guru mengadakan evaluasi hasil, Tindak lanjut, yaitu pemberian tugas rumah sebagai pendalaman. Sedangkan Roestiyah (2012:81) menyatakan bahwa bila siswa akan melaksanakan suatu eksperimen perlu memperhatikan prosedur sebagai berikut: (a) Perlu dijelaskan kepada siswa tentang tujuan eksperimen, mereka harus memahami masalah yang akan dibuktikan melalui eksperimen, (b) Kepada siswa perlu diterangkan pula tentang : Alat-alat serta bahan-bahan yang akan digunakan dalam percobaan, Agar tidak mengalami kegagalan siswa perlu mengetahui variabelvariabel yang harus dikontrol dengan ketat, Urutan yang akan ditempuh sewaktu eksperimen berlangsung, Seluruh proses atau hal-hal yang penting saja yang akan dicatat.perlu menetapkan bentuk catatan atau laporan berupa uraian, perhitungan, grafik dan sebagainya, Selama eksperimen berlangsung, guru harus mengawasi pekerjaan siswa. Bila perlu memberi saran atau pertanyaan yang menunjang kesempurnaan jalannya eksperimen, Setelah eksperimen selesai, guru harus mengumpulkan hasil penelitian siswa, mendiskusikan ke kelas; dan mengevaluasi dengan tes atau sekedar tanya jawab.

\section{Metode Penelitian}

Penelitian tindakan kelas ini dilakukan pada semester I tahun pelajaran 2019/2020 selama 2 bulan yaitu dari bulan Oktober sampai dengan bulan Nopember 2019. Berikut tabel jadwal penelitian tindakan kelas Penelitian ini dilaksanakan di kelas VII H SMP MTA Gemolong Kabupaten Kabupaten Sragen dengan pertimbangan peneliti dan juga mengajar di kelas tersebut dan memahami berbagai permasalahan yang ada. Subyek dalam penelitian tindakan kelas ini adalah peserta didik kelas VII H SMP MTA Gemolong Tahun Pelajaran 2019/2020, sebanyak 32 peserta didik yang terdiri dari 32 peserta didik perempuan. Kelas 
ini termasuk sebagai kelas bermasalah, kondisi kelas sering kurang kondusif pada saat pembelajaran berlangsung. Sebagian peserta didik cenderung pasif dan kurang kreatif. Akibatnya keaktifan dan hasil belajar peserta didik relatif rendah dibanding dengan kelas yang lain. Adapun obyek penelitian ini adalah : (1) Keaktifan belajar, (2) Hasil belajar, (3) Metode eksperimen. Sumber data dalam penelitian ini yang akan di kumpulkan bersumber dari : (1) Sumber data primer yang diperoleh dari peserta didik melalui tes tertulis, (2) Sumber data sekunder yang diperoleh dari hasil observasi, jurnal dan refleksi. Adapun bentuk data yang didapat dari penelitian ini adalah: (1) Data kuantitatif merupakan data hasil belajar peserta didik yang diambil dengan cara memberikan tes kepada peserta didik setelah selesai tindakan, (2) Data kualitatif untuk mengetahui tingkat keaktifan belajar diperoleh dari hasil pengamatan peneliti serta mitra kolaborator selama pelaksanaan tindakan tiap siklus dengan menggunakan instrumen observasi kegiatan guru dan peserta didik pada saat kegiatan belajar mengajar. Untuk data keaktifan peserta didik diperoleh dari dokumen pengamatan dan data hasil belajar yang diperoleh dari dokumen daftar nilai tes. Teknik pengumpulan data yang dilakukan pada penelitian ini adalah teknik tes, teknik nontes berupa observasi, dokumentasi. Validasi Data. Untuk menjamin validitas data dan pertanggungjawaban yang dapat dijadikan dasar yang kuat untuk menarik kesimpulan, maka yang digunakan untuk memeriksa validitas data yaitu, hasil belajar dengan validitas isi dan keaktifan peserta didik dengan teknik trianggulasi.

Tehnik Analisis Data Dalam penelitian ini terdapat 3 macam data aktifitas belajar yaitu data kondisi awal, data siklus I dan data siklus II. Data tiga aktifitas tersebut dianalisa menggunakan teknik deskriptif komparatif dilanjutkan dengan refleksi. Analisis deskriptif komparatif yaitu dengan membandingkan data aktifitas kondisi awal dengan siklus I, siklus I dengan siklus II dan kondisi awal dengan siklus II. Sedangkan refleksi dilakukan untuk membuat kesimpulan apakah siklus perlu dilanjutkan apa tidak. Analisis data hasil belajar berupa data kuantitatif yang diperoleh dari hasil tes kemudian diolah dengan mengunakan rumus Persentase hasil belajar diperoleh untuk menentukan tingkat hasil belajar Suhu dan Perubahannya. Hasil tes dimaksud di atas adalah hasil tes kondisi awal, hasil tes siklus I dan hasil tes siklus II. Hasil tersebut dianalisa menggunakan teknik deskriptif komparatif. Analisis deskriptif komparatif yaitu dengan membandingkan data hasil belajar kondisi awal dengan hasil belajar siklus I, hasil belajar siklus I dengan hasil belajar siklus II dan membandingkan hasil belajar kondisi awal dengan hasil belajar siklus II. Penelitian Tindakan kelas ini dilaksanakan dalam dua siklus yang masing-masing siklus terdiri dari 2 pertemuan dengan durasi waktu 2 x 40 menit tiap-tiap pertemuan. Adapun objek penelitian ini adalah metode eksperimen, aktifitas belajar peserta didik dan hasil belajar peserta didik. Rentang waktu untuk penelitian ini selama 5 bulan yaitu dimulai bulan Juli dan berakhir bulan Nopember. Penelitian dilakukan pada peserta didik kelas VII H SMP MTA Gemolong Semester I tahun pelajaran 2019/ 2020. Indikator keberhasilan dikatakan berhasil bila: (1) Prosentase keaktifan rata-rata 75\%, (2) Nilai Pengetahuan rata-rata pada akhir siklus minimal mencapai 75. (3) Ketuntasan belajar secara klasikal mencapai 85\%.

\section{Hasil Penelitian}

Adapun keaktifan belajar peserta didik mengalami peningkatan dibandingkan

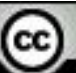


dengan Siklus I. Keaktifan belajar peserta didik mengalami peningkatan dari $70.00 \%$ pada Siklus I menjadi $76.25 \%$ pada Siklus II. Untuk lebih jelasnya peningkatan keaktifan belajar peserta didik dapat dilihat pada Tabel 1. Demikian juga hasil belajar peserta didik kompetensi pengetahuan mengalami peningkatan yaitu dari rata-rata 71,28 pada Siklus I menjadi 76,03 pada Siklus II, sedangkan peserta didik yang mencapai ketuntasan sebanyak 18 peserta didik atau 56,25\% pada Siklus I menjadi 28 peserta didik atau 87,50\% pada Siklus II. Untuk lebih jelasnya peningkatan hasil belajar kompeensi pengetahuan dapat dijelaskan pada Tabel 2.

Tabel 1. Data Peningkatan Keaktifan Belajar Peserta Didik Siklus II

\begin{tabular}{|c|c|c|c|c|c|c|}
\hline \multirow{2}{*}{ No. } & \multirow{2}{*}{ Aspek Yang Diuji } & \multirow{2}{*}{ Data } & \multicolumn{2}{|c|}{ Siklus I } & \multicolumn{2}{|c|}{ Siklus II } \\
\hline & & & Keaktifan & $\%$ Keaktifan & Keaktifan & $\%$ Keaktifan \\
\hline 1 & $\begin{array}{l}\text { Aktif memperhatikan } \\
\text { penjelasan guru }\end{array}$ & 32 & 20 & $62,50 \%$ & 24 & $75,00 \%$ \\
\hline 2 & Aktif dalam kelompok & 32 & 24 & $75,00 \%$ & 23 & $71,88 \%$ \\
\hline 3 & Aktif berdiskusi kelompok & 32 & 23 & $71,88 \%$ & 25 & $78,13 \%$ \\
\hline 4 & $\begin{array}{l}\text { Aktif bekerjasama dalam } \\
\text { kelompok }\end{array}$ & 32 & 22 & $68,75 \%$ & 25 & $78,13 \%$ \\
\hline 5 & $\begin{array}{l}\text { Aktif mendengarkan } \\
\text { pendapat teman lain }\end{array}$ & 32 & 23 & $71,88 \%$ & 25 & $78,13 \%$ \\
\hline \multicolumn{3}{|c|}{ Rata-rata Keaktifan Belajar } & & $70,00 \%$ & & $76,25 \%$ \\
\hline
\end{tabular}

Tabel 2. Data Peningkatan Hasil Belajar Kompetensi Pengetahuan Siklus II

\begin{tabular}{lcc}
\hline \multicolumn{1}{c}{ Keterangan } & Siklus I & Siklus II \\
\hline Jumlah Data & 32 & 32 \\
Nilai Terendah & 60 & 65 \\
Nilai Tertinggi & 92 & 95 \\
Rata-rata & 71,25 & 76,41 \\
Yang Tuntas & 18 & 28 \\
Persentase Yang Tuntas & $56,25 \%$ & $87,50 \%$ \\
Yang Tidak Tuntas & 14 & 4 \\
Persentase & $43,75 \%$ & $12,50 \%$ \\
Yang Tidak Tuntas & & \\
\hline
\end{tabular}

Sedangkan hasil belajar peserta didik kompetensi keterampilan juga mengalami peningkatan pada Siklus II dibandingkan dengan Siklus I yaitu dari rata-rata 70,28 menjadi 75,94, sedangkan peserta didik yang tuntas tuntas belajar mengalamai peningkatan dari 23 peserta didik atau 71,88\% menjadi 29 peserta didik atau 90,63\%. Peningkatan hasil belajar kompetensi keterampilan dijelaskan pada Tabel 3.

Tabel 3. Data Peningkatan Hasil Belajar Kompetensi Keterampilan Siklus II

\begin{tabular}{lcc}
\hline \multicolumn{1}{c}{ Keterangan } & Siklus I & Siklus II \\
\hline Jumlah Data & 32 & 32 \\
Nilai Terendah & 64 & 68 \\
Nilai Tertinggi & 78 & 88 \\
Rata-rata & 70,28 & 75,94 \\
Yang Tuntas & 23 & 29 \\
Persentase Yang Tuntas & $71,88 \%$ & $90,63 \%$ \\
Yang Tidak Tuntas & 9 & 3 \\
Persentase & $28,13 \%$ & $9,38 \%$ \\
Yang Tidak Tuntas & & \\
\hline
\end{tabular}

Pembahasan 
Keaktifan peserta didik dalam proses pembelajaran pada kondisi awal masih rendah. Metode eksperimen dapat meningkatkan keaktifan peserta didik pada proses pembelajaran materi relasi dan fungsi. Peningkatan tersebut dapat disajikan sebagai berikut: Peserta didik yang aktif memperhatikan penjelasan guru pada kondisi awal 15 peserta didik atau 46.88\%, pada siklus I terjadi peningkatan yaitu menjadi 20 peserta didik atau $62.50 \%$, pada siklus II terjadi yaitu menjadi 24 peserta didik atau $75.00 \%$. Peserta didik yang aktif di dalam kelompok pada kondisi awal 18 peserta didik atau 56,25\%, pada siklus I terjadi peningkatan sebesar $18.75 \%$ yaitu meningkat menjadi 24 peserta didik atau $75.00 \%$, pada siklus II terjadi peningkatan sebesar $3.12 \%$ yaitu menjadi 23 peserta didik atau $71.88 \%$. Peserta didik yang aktif dalam diskusi kelompok pada kondisi awal 19 peserta didik atau $59.38 \%$, pada siklus I terjadi peningkatan sebesar $12.5 \%$ yaitu meningkat menjadi 23 pserta didik atau $71.88 \%$, pada siklus II terjadi peningkatan sebesar $6.25 \%$ yaitu menjadi 25 peserta didik atau 78,13\%. Peserta didik yang aktif bekerjasama dalam kelompok masalah pada kondisi awal 16 peserta didik atau 50.00\%, pada siklus I terjadi peningkatan sebesar $18.75 \%$ yaitu meningkat menjadi 22 peserta didik atau $68.75 \%$, pada siklus II terjadi peningkatan sebesar $9.38 \%$ yaitu menjadi 25 peserta didik atau $78.13 \%$. Peserta didik yang aktif mendengarkan pendapat teman lain masalah pada kondisi awal 17 peserta didik atau $53.13 \%$, pada siklus I terjadi peningkatan sebesar $18.75 \%$ yaitu meningkat menjadi 23 pserta didik atau $71.88 \%$, pada siklus II terjadi peningkatan sebesar $6.25 \%$ yaitu menjadi 25 peserta didik atau $78.13 \%$. Sedangkan rata-rata Keaktifan Peserta didik masalah pada kondisi awal 53.13\%, pada siklus I terjadi peningkatan sebesar $23.12 \%$ yaitu meningkat menjadi $70.00 \%$, pada siklus II terjadi peningkatan sebesar $6.25 \%$ yaitu menjadi $76.25 \%$. Untuk lebih jelasnya dapat disajikan dalam Tabel 4.

Tabel 4. Peningkatan Keaktifan Peserta Didik

\begin{tabular}{|c|c|c|c|c|c|c|c|c|}
\hline No & $\begin{array}{c}\text { Aspek yang } \\
\text { diamati }\end{array}$ & & $\begin{array}{l}\text { ndisi } \\
\text { wal }\end{array}$ & & iklus I & $\begin{array}{l}\text { Mening } \\
\text { kat }(\%)\end{array}$ & Siklus II & Meningkat (\%) \\
\hline 1 & $\begin{array}{l}\text { Aktif } \\
\text { memperhatika } \\
\text { n penjelasan } \\
\text { guru }\end{array}$ & 15 & $\begin{array}{c}46.88 \\
\%\end{array}$ & 20 & $62.50 \%$ & $15.62 \%$ & $24 \quad 75.00 \%$ & $12.50 \%$ \\
\hline 2 & $\begin{array}{l}\text { Aktif didalam } \\
\text { kelompok }\end{array}$ & 18 & $\begin{array}{c}56.25 \\
\%\end{array}$ & 23 & $71.88 \%$ & $18.75 \%$ & $24 \quad 75.00 \%$ & $3.12 \%$ \\
\hline 3 & $\begin{array}{l}\text { Aktif } \\
\text { berdiskusi } \\
\text { kelompok }\end{array}$ & 19 & $\begin{array}{l}59.38 \\
\%\end{array}$ & 23 & $71.88 \%$ & $12.50 \%$ & $2578.13 \%$ & $6.25 \%$ \\
\hline 4 & $\begin{array}{l}\text { Aktif } \\
\text { bekerjasama } \\
\text { dalam } \\
\text { kelompok }\end{array}$ & 16 & $\begin{array}{c}50.00 \\
\%\end{array}$ & 22 & $68.75 \%$ & $18.75 \%$ & $2578.13 \%$ & $9.38 \%$ \\
\hline 5 & $\begin{array}{l}\text { Aktif } \\
\text { mendengarkan }\end{array}$ & 17 & $\begin{array}{c}53.13 \\
\%\end{array}$ & 23 & $71.88 \%$ & $18.75 \%$ & $2578.13 \%$ & $6.25 \%$ \\
\hline
\end{tabular}




\begin{tabular}{l} 
pendapat \\
teman lain \\
$\begin{array}{l}\text { Rata-rata } \\
\text { Keaktifan Peserta } \\
\text { didik }\end{array}$ \\
\hline
\end{tabular}

Peningkatan keaktifan peserta didik pada materi suhu dan perubahannya dapat diperhatikan pada histogram Gambar 1.

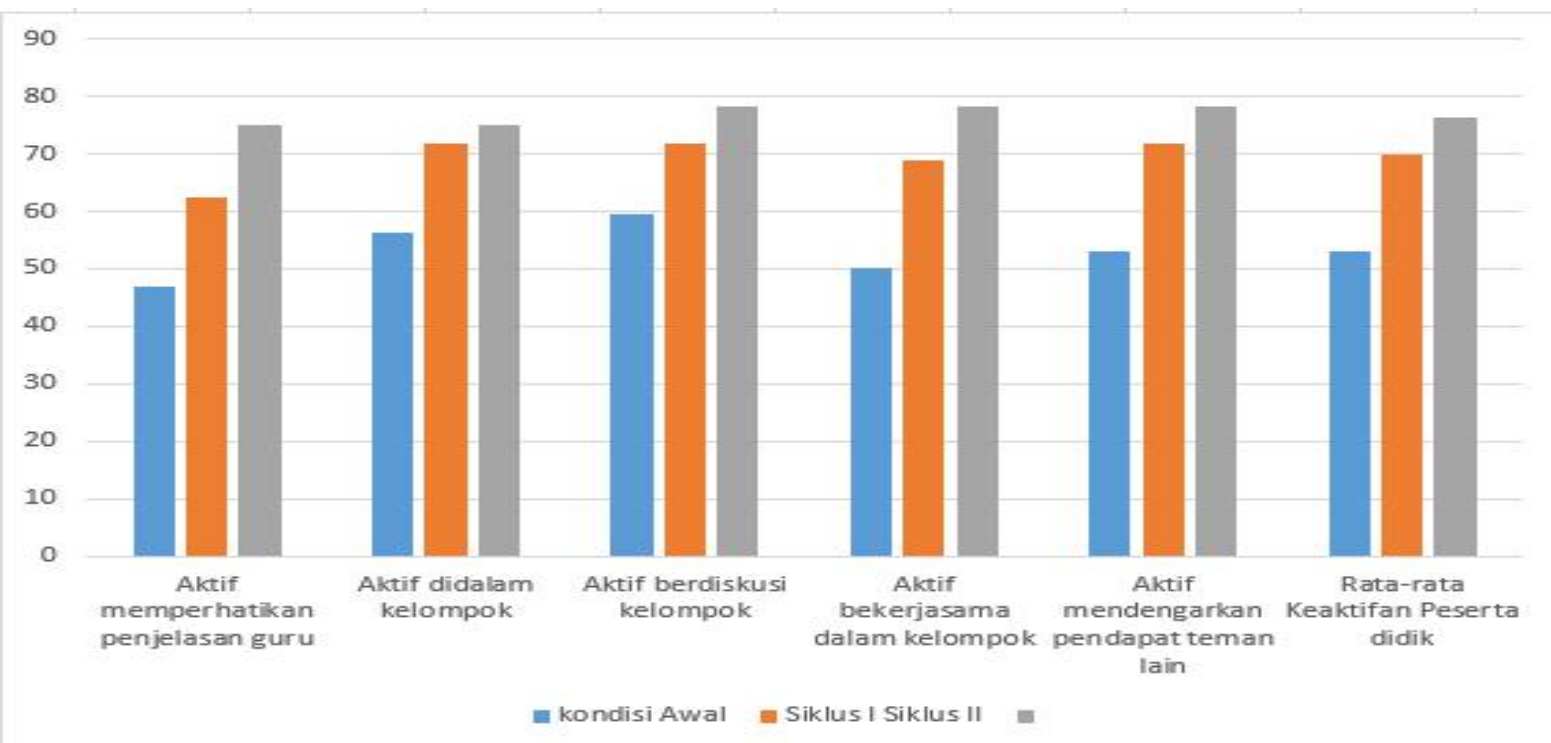

Gambar 1. Histogram Keaktifan siswa Diakhir Siklus I

Dengan memperhatikan tabel dan grafik keaktifan belajar peserta didik di atas menunjukkan makin meningkat dari kondisi awal ke kondisi akhir. Peningkatan rata-rata keaktifan belajar dari kondisi awal ke siklus I mencapai $16,87 \%$ dan peningkatan dari siklus I ke siklus II mencapai 6,25\%. Pada siklus II rata-rata keaktifan belajar peserta didik mencapai $76,25 \%$. Pencapaian pada siklus II tersebut sudah menunjukkan angka yang melampaui batas minimal pada indikator keberhasilan sebesar $75 \%$. Dengan demikian dapat disimpulkan sementara bahwa penerapan metode ekperimen dapat meningkatkan keaktifan belajar materi suhu dan perubahannya pada peserta didik kelas VII H Semester Ganjil SMP MTA Gemolong Tahun Pelajaran 2019/2020.

Berdasarkan uraian tabel di atas diperoleh data bahwa nilai hasil belajar peserta didik materi suhu dan perubahannya semakin meningkat. Pada kondisi awal hasil belajar peserta didik materi suhu dan perubahannya. Nilai rata-rata peserta didik untuk tes pengetahuan hanya 67,19 dan nilai rata-rata tes keterampilan hanya 68,16 . Nilai rata-rata dibawah KKM tersebut, diiringi dengan jumlah peserta didik yang tuntas hanya 14 peserta didik untuk tes pengetahuan dan 17 peserta didik untuk tes keterampilan. Setelah dilakukan tindakan pada siklus I, nilai rata-rata kelas meningkat menjadi 72,25 untuk tes pengetahuan dengan jumlah peserta didik yang tuntas mencapai 18 peserta didik atau 56,25\%. 
Sedangkan untuk tes keterampilan, nilai rata-rata mencapai 70,28 dengan jumlah peserta didik yang tuntas sebanyak 23 peserta didik atau $71,88 \%$. Hasil belajar pada materi suhu dan perubahannya semakin meningkat pada siklus II. Untuk tes pengetahuan, nilai rata-rata kelas menjadi 76,41 dengan jumlah peserta didik yang tuntas 28 orang atau $87,50 \%$. Sedangkan untuk tes keterampilan, nilai rata-rata mencapai 75,94 dengan jumlah peserta didik yang tuntas 29 orang atau 90,63\%. Peningkatan hasil belajar materi suhu dan perubahannya kondisi awal, dibandingkan dengan hasil belajar siklus I dan siklus II dapat dilihat pada Tabel 5.

Tabel 5. Peningkatan Hasil Belajar Peserta Didik

\begin{tabular}{llcccccc}
\hline \multirow{2}{*}{ No } & \multirow{2}{*}{ Keterangan } & \multicolumn{2}{c}{ Kondisi Awal } & \multicolumn{2}{c}{ Siklus I } & \multicolumn{2}{c}{ Siklus II } \\
\cline { 3 - 8 } & & $\begin{array}{c}\text { Pengeta } \\
\text { huan }\end{array}$ & $\begin{array}{c}\text { Ketram } \\
\text { pilan }\end{array}$ & $\begin{array}{c}\text { Pengeta } \\
\text { huan }\end{array}$ & $\begin{array}{c}\text { Ketram } \\
\text { pilan }\end{array}$ & $\begin{array}{c}\text { Pengeta } \\
\text { huan }\end{array}$ & $\begin{array}{c}\text { Ketrampil } \\
\text { an }\end{array}$ \\
\hline 1 & Nilai Terendah & 45 & 60 & 60 & 64 & 65 & 68 \\
2 & Nilai Tertinggi & 90 & 80 & 92 & 90 & 95 & 95 \\
3 & Nilai Rata-rata kelas & 67.19 & 68.16 & 72.25 & 70.28 & 76.41 & 76.16 \\
4 & Yang Tuntas & 14 & 17 & 18 & 23 & 28 & 29 \\
5 & Persentase yang tuntas & $43.75 \%$ & $53.13 \%$ & $56.25 \%$ & $71.88 \%$ & $87.50 \%$ & $90.63 \%$ \\
6 & Yang tidak tuntas & 18 & 15 & 14 & 9 & 4 & 3 \\
7 & PersentaseYang tidak tuntas & $56.25 \%$ & $46.88 \%$ & $43.75 \%$ & $28.13 \%$ & $12.50 \%$ & $9.36 \%$ \\
\hline
\end{tabular}

Untuk lebih jelasnya disajikan histogram yang memuat rata-rata kelas dan banyaknya peserta didik yang tuntas untuk kompetensi pengetahuan pada kondisi awal, siklus I dan siklus II sebagai berikut:

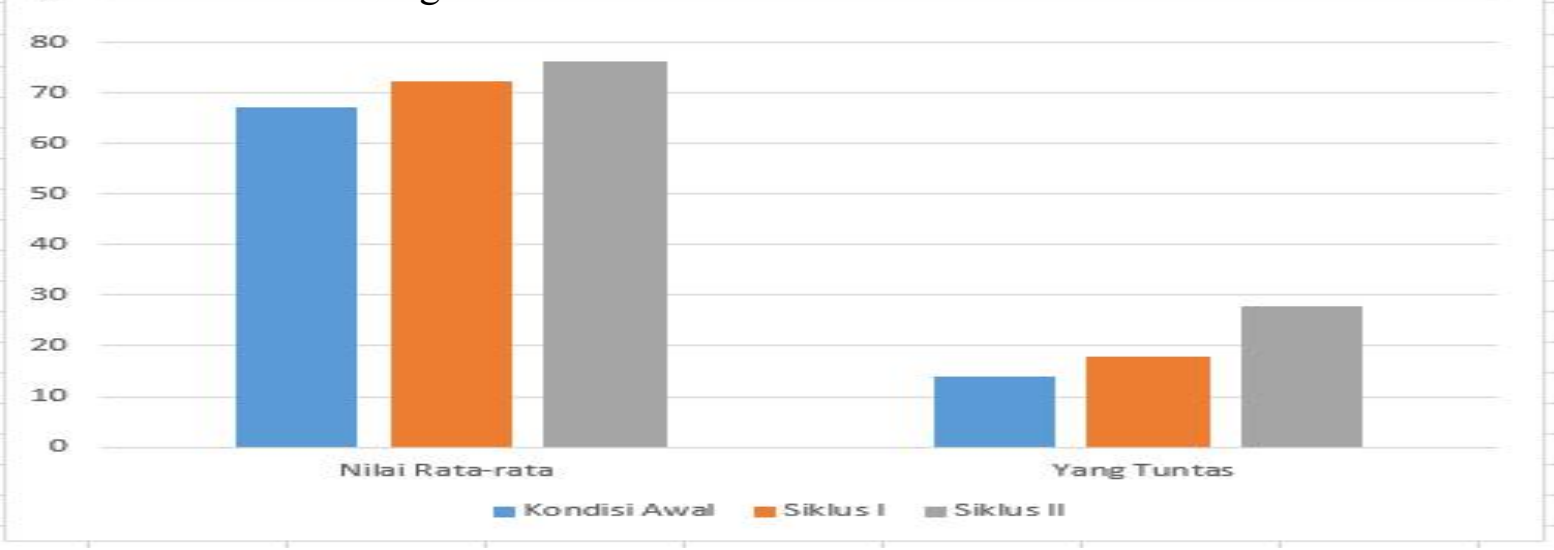

Gambar 2. Histogram Peningkatan Hasil Belajar Kompetensi Pengetahuan

Kesimpulan sementara yang dapat diperoleh dari hasil analisis data tersebut adalah bahwa kegiatan pembelajaran dengan penerapan metode eksperimen ternyata cukup efektif terhadap peningkatan keaktifan dan hasil belajar peserta didik. Berdasarkan simpulan sementara pada siklus I dan II bahwa hipotesis tindakan dalam penelitian tindakan kelas ini yakni : dengan penerapan metode eksperimen dapat meningkatkan hasil belajar IPA materi suhu dan perubahannya bagi peserta didik kelas VII H SMP MTA Gemolong Kabupaten 
Sumargo, Peningkatan Keaktifan dan Hasil Belajar IPA Melalui Metode Eksperen...251

Sragen semester I tahun pelajaran 2019/2020, dapat diterima.

\section{Simpulan dan Saran}

Dengan memperhatikan hasil analisis dan pembahasan hasil penelitian yang telah dilaksanakan dalam proses pembelajaran materi Suhu dan perubahannya dengan metode eksperimen maka dapat disimpulkan sebagai berikut: (1) Telah terjadi peningkatan keaktifan belajar peserta didik pada pembelajaran materi relasi dan fungsi bagi peserta didik SMP MTA Gemolong pada semester ganjil tahun pelajaran 2019/2020 dengan hasil peningkatan rata-rata keaktifan belajar dari kondisi awal ke siklus I mencapai 13,12\% dan peningkatan dari siklus I ke siklus II mencapai 6,35\%. Pada siklus II rata-rata keaktifan belajar peserta didik mencapai $76,25 \%$. Pencapaian pada siklus II tersebut sudah menunjukkan angka yang melampaui batas minimal pada indikator keberhasilan sebesar $75 \%$. Dengan demikian dapat disimpulkan bahwa penerapan metode eksperimen dapat meningkatkan keaktifan belajar materi suhu dan perubahannya pada peserta didik kelas VII H semester ganjil SMP MTA Gemolong tahun pelajaran 2019/2020, (2) Terdapat peningkatan prestasi belajar peserta didik pada pembelajaran materi suhu dan perubahannya bagi peserta didik kelas VII H SMP MTA Gemolong .pada semester ganjil tahun pelajaran 2019/2020 dengan hasil nilai rata-rata kelas hasil tes pengetahuan dari kondisi awal adalah 67,19 dan pada siklus I nilai rata-rata kelas meningkat menjadi 72,25 sedangkan nilai ratarata pada siklus II meningkat menjadi 76,41 dengan demikian dari kondisi awal kemudian siklus I sampai siklus II terdapat peningkatan nilai tes pengetahuan. Sedangkan persentase jumlah siswa yang tuntas dari kondisi awal $43,75 \%$, kemudian pada siklus I yaitu meningkat menjadi $56,25 \%$ dan pada Siklus II menjadi $87,50 \%$. Hal itu berarti bahwa pembelajaran dengan penerapan metode eksperimen dapat meningkatkan prestasi belajar peserta didik kelas VII H SMP MTA Gemolong semester ganjil tahun pelajaran 2019/2020.

Berdasarkan simpulan tersebut di atas, maka penulis menyampaikan beberapa saran antara lain: 1) Dalam proses pembelajaran guru hendaknya memperhatikan karakter materi dan metode pembelajaran yang tepat sehingga dapat melibatkan keatifan siswa salah satunya dengan menggunakan metode eksperimen; 2) Guru hendaknya mengkaji permasalahan yang timbul selama proses pembelajaran sehingga siswa lebih aktif dan pembelajaran lebih baik; 3) Siswa diharapkan memiliki keaktifan yang tinggi dalam mengikuti proses pembelajaran sehingga terlihat hidup dan dinamis yang pada gilirannya dapat meningkatan prestasi belajar peserta didik; 4) Bagi siswa yang kurang paham hendaknya aktif bertanya kepada guru atau teman yang lebih paham; 5) Hal-hal yang menjadi kesulitan dalam belajar sebaiknya disampaikan kepada guru.

\section{Daftar Rujukan}

Abimanyu, Soli. dkk. (2008). Strategi Pembelajaran. Jakarta: Direktorat Jendral Pendidikan Tinggi Departemen Pendidikan Nasional

Dahar, R. W. (2006). Teori-teori Belajar dan Pembelajaran. Bandung: Erlangga

Giyono. (2020). Penerapan Metode Cooperative Integrated Reading Compasition untuk Meningkatkan Motivasi dan Hasil Belajar Bahasa Indonesia Kelas X-IPS 2 SMA 
Negeri 1 GemolongTahun Pelajaran 2019/2020. Jurnal Pendidikan. Volume 28(2), Juli 2020.

Hamalik, Oemar. (2004).Proses Belajar Mengajar. Jakarta: Bumi Aksara Hermawan, A.H. dkk. (2007). Belajar dan Pembelajaran SD. Bandung: UPI Press

Jihad, A. dan Abdul Haris. (2012). Evaluasi Pembelajaran. Yogyakarta: Multi Presindo.

Mayangsari, Dewi. dkk. (2014). Penerapan Metode Eksperimen Untuk Meningkatkan Aktivitas dan Hasil Belajar IPA Siswa Kelas VI Pokok Bahasan Konduktor dan Isolator SDN Semboro Probolinggo Tahun Pelajaran 2012/2013. Jurnal Edukasi UNEJ, I (1): Hal: 27-31

.(2012). Strategi Belajar Mengajar. Jakarta: Rineka Cipta

Sardiman, A.M. (2011). Interaksi \& Motivasi Belajar Mengajar. Jakarta: Raja Grafindo Persada

Sudjana, Nana. (2005). Hasil dan Proses Belajar Mengajar. Bandung: Remaja Rosdakarya. . (2009). Metode Statistika. Bandung: Tarsito.

Sumantri, $\bar{M}$ dan Permana (1999). Strategi Belajar Mengajar. Bandung: Alfabeta

Susanto, Ahmad. (2013). Teori Belajar dan Pembelajaran di Sekolah Dasar. Jakarta: Kencana Prenadamedia Group.

Syah, Muhibbin. (2012). Psikologi Belajar. Jakarta: Raja Grafindo Persada.

Warsono dan Hariyanto. (2013). Pembelajaran Aktif. Bandung: Remaja Rosdakarya. 